\title{
The Effect of Capital Adequacy, Market Risk, Credit Risk, Operational Risk and Liquidity on the Profitability (Case Study on Sharia Banks Registered in OJK Period 2010-2019)
}

\author{
Yulia Sandra Sari ${ }^{1 *}$, Anindya Ardiansari ${ }^{1}$, Syam Widia ${ }^{1}$
}

\author{
${ }^{1}$ Universitas Negeri Semarang \\ *Corresponding author. Email: yuliasandra@students.unnes.ac.id
}

\begin{abstract}
Banking is a financial institution that has a role in the financial system in Indonesia. The existence of the banking sector becomes important because in carrying out life in the community involves services from the banking sector. Banking is an institution that has a strategic role as a financial intermediary (financial intermediary) between parties who have funds (surplus funds) with parties who need funds (deficit funds), as well as institutions that function to facilitate payment-traffic. The Islamic banking sector has not escaped in the role and dynamics of banking in Indonesia. However, its existence still needs to be questioned. One of the bank's health assessment efforts can be done through financial performance assessment. The financial performance of the bank can be seen from the profitability of the bank. This research aims to find out the health of Islamic banks in Indonesia using financial ratios. This study used data from 2010-2019 with 9 Islamic Banks sampled. Testing uses description analysis and regression. The results showed that NOM and BOPO had a significant influence on ROA in the Islamic banking sector in Indonesia.
\end{abstract}

Keywords: Bank Syariah, Profitability, financial performance, financial ratio, credit risk, Banking.

\section{INTRODUCTION}

Banking is a financial institution that has a role in the financial system in Indonesia. The existence of the banking sector becomes important because in carrying out life in the community involves services from the banking sector. Banking is an institution that has a strategic role as a financial intermediary between parties who have funds (surplus funds) with parties who need funds (deficit funds), as well as institutions that function to facilitate payment traffic. In addition, the bank is also an agent of trust where the bank bases its business activities on public trust, and as an agent of development where the bank serves as national economic development [26].

According to the Law No. 10 of 1998, banks are business entities that collect funds from the community and distribute to the community in the form of credit and other forms in order to improve people's standard of living. In terms of rewards or services for the use of funds, deposits or loans, banks are distinguished into conventional banks and Islamic banks [34]. The difference between conventional banks and Islamic banks lies in the rewards that banks pay or receive to customers.

In conventional banks provide rewards in the form of interest while in Islamic banks the reward refers to Islamic law where the rewards received or paid by the customer depend on the agreement between the bank and the customer [67].

For banks that run their business using sharia principles do not recognize the term profit or interest in performing loan or storage services. In Islamic banks the services provided in accordance with sharia principles or Islamic teachings. The principles applied include financing based on the principle of profit sharing (mudharabah), financing based on capital participation (musyarakah), the principle of buying and selling goods by obtaining profits (murabahah), or the distribution of capital goods based on the principle of pure rent without choice (ijarah) or with the option 
of transferring ownership of goods rented from the bank by other parties (ijarah wa iqtina).

Currently, the growth of banking in Indonesia is progressing rapidly. This happens to conventional banks and Islamic banks supported by Law No. 21 of 2008 on Islamic banking which provides a clearer operating foundation for Islamic banks. So it does not rule out the possibility that people using Islamic banks will be higher and able to increase the significance of the banking industry to support the stability of the national financial system [20].

Table 1. Development of Sharia Commercial Bank in 2019

\begin{tabular}{|l|l|}
\hline \multicolumn{1}{|c|}{ Indicators } & Sharia Commercial Bank \\
\hline Credits & Rp 355 trillion/6,25\% \\
\hline DPK & $\operatorname{Rp~416~trillion/6,~93\% ~}$ \\
\hline Assets & Rp 350 trillion/4,92\% \\
\hline
\end{tabular}

Source: OJK (data processed, 2021)

Table 1 provides information on the development of Islamic banking as of 2019. According to credit indicators, Islamic banks amount to Rp 355 trillion or $6.25 \%$ of conventional banking. According to the indicators of the Third-Party Funds (DPK in Indonesia) the sharia law Rp 416 trillion at. While in terms of assets owned by Islamic banking amounted to 350 trillion or $4.92 \%$.

One of the bank's health assessment efforts can be done through financial performance assessment. The financial performance of the bank can be seen from the profitability of the bank. Profitability or the ability to earn profits is a measure in the form of percentages used to assess the extent to which the company is able to generate profits at the level received by [38].

Banks that have high profitability show good financial performance. Profitability indicates the company's future prospect. In addition, the company's good financial performance will attract investors to invest in the company [6]. The measure of profitability used is Return on Assets (ROA). ROA is used because it is more representative in showing the measure of banking profitability. On the other hand, Bank Indonesia pays special attention to ROA compared to ROE because it prioritizes the profitability value of a bank as measured by assets that some of its funds come from community deposits [24]. ROA is important for banking because ROA is used to measure the effectiveness of companies in making profits by utilizing assets owned [17]. In addition, ROA is used to measure the ability of bank management in obtaining profits (pre-tax profits) generated from the average total assets of the bank concerned. The greater the ROA, the greater the level of profit achieved by the bank so that the possibility of a bank in a troubled condition is smaller.

Figure 1. shows the movement of ROA in Islamic banks during 2010-2019. Significant declines occurred in 2013-2016. Then the upward trend of ROA occurred in 2018-2019. The OJK report in the Sharia Banking Statistics Book in 2019 reported a Sharia bank ROA of $1.73 \%$.

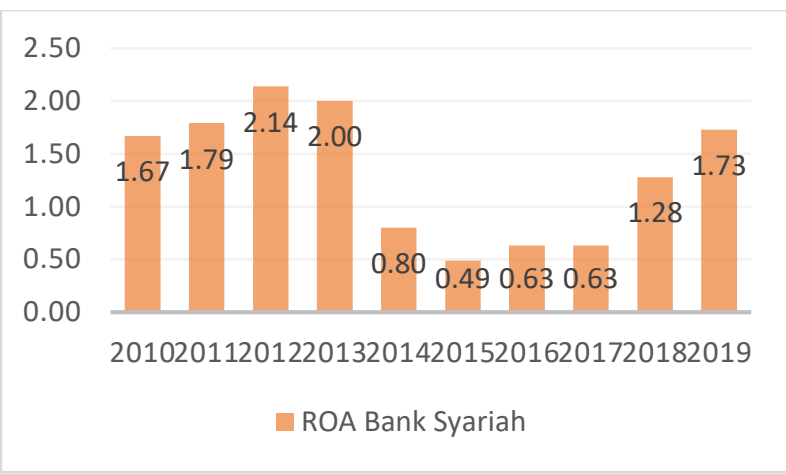

Source: OJK (data processed, 2021).

Figure 1. ROA of Islamic Bank.

Continued with a discussion about the factors that affect ROA. In the study [43] several factors that can affect ROA such as CAR, BOPO, NPL, NIM and LDR. CAR is a financial ratio related to banking capital where the amount of capital of a bank will reflect the ability to carry out business activities efficiently or inefficiently.

According to research conducted by [25] using a sample of National Foreign Exchange-listed Private Commercial Banks on the Indonesia Stock Exchange that examined the influence of CAR, LDR, NIM on ROA resulted in the finding that CAR has a significant positive influence on ROA. Similar to the research conducted by [46] which conducted research on private commercial banks registered with the IDX which resulted in research that there was a significant positive influence on ROA.

In contrast to the results of the above research conducted by [1] using variables CAR, LDR, NPL against ROA in the banking sector in 2014-2018 resulted in the finding that CAR has a significant negative effect on ROA. Supported by research [53] that CAR has a negative and significant influence on ROA. But research conducted by [43] revealed that CAR has a negative and insignificant effect on ROA. This is in the bi provision that the bank has a car of at least $8 \%$ which results in the bank having to prepare a reserve fund for the minimum provision. 
On the other hand, a bank must be prepared in the face of various events by taking all sources of market risk that can be controlled and prevent negative impacts that exceed the amount that can be borne by the bank's capital. Market risk includes risks due to changes in interest rates and exchange rates. Where interest rate risk is related to the movement of interest rates against the repricing gap between assets and pasiva. One indicator to measure market risk is to use the Net Interest Margin (NIM) proxy. This ratio illustrates the magnitude of the level of net interest income to the use of productive assets owned by banks. So, the increase in NIM means that interest income earned from the use of productive assets also increases the possibility of bank problems getting smaller [62]. This is in accordance with the theory of profit management efficiency where banks can utilize productive assets well will increase profitability. [63].

According to research [9] states that NIM has a significant positive influence on ROA in commercial banks in the IDX in 2012-2015. Supported by the results of research conducted by [8] which used a sample of research on commercial banks to go public in the period 2011-2014 stated that NIM has a positive and significant effect on ROA. [36] research found that NIM has a positive and insignificant effect on ROA. In contrast to the results of study [3] which used CAR variables, LDR, NIM to explain ROA variables resulted in the finding that NIM has a negative and significant influence on ROA.

According to research conducted by Nuryanto et al. [39] which tested CAR, LDR, NPL and BOPO shades against ROA in conventional banks that went public in 2014-2018 revealed that NPL has a negative and significant influence on ROA. The results are in line with research conducted by [14]. Research conducted by [10] states that NPL has a negative and insignificant relationship. In contrast to the results of study [65] which states that NPL has a positive and significant influence on ROA.

According to research conducted by [13] stated that BOPO has a negative and significant effect on ROA in the banking sector listed on the IDX. Supported by the results of research conducted by [20] revealed that the BOPO ratio has a negative and significant influence on ROA on Islamic Commercial Banks. Research conducted by Nugroho et al. [38] resulted in the finding that $\mathrm{BOPO}$ has a negative and unsuitable influence on ROA. A summary of previous studies is presented in Table 2 as follows:
Table 2 Research Gap

\begin{tabular}{|c|c|c|c|c|}
\hline $\begin{array}{l}\text { Researc } \\
\text { h Gap }\end{array}$ & Issues & $\begin{array}{l}\text { Researcher } \\
\text { S }\end{array}$ & Result & $\begin{array}{l}\text { Context } \\
\text { of } \\
\text { Researc } \\
\text { h }\end{array}$ \\
\hline \multirow[t]{4}{*}{$\begin{array}{l}\text { Differenc } \\
\text { es in car } \\
\text { research } \\
\text { results } \\
\text { on ROA }\end{array}$} & \multirow{4}{*}{$\begin{array}{l}\text { The } \\
\text { higher } \\
\text { the } \\
\text { CAR, } \\
\text { the } \\
\text { better } \\
\text { the } \\
\text { financ } \\
\text { ial } \\
\text { perfor } \\
\text { mance } \\
\text { of a } \\
\text { compa } \\
\text { ny. } \\
\text { CAR } \\
\text { has a } \\
\text { positiv } \\
\text { e } \\
\text { effect } \\
\text { on } \\
\text { ROA }\end{array}$} & $\begin{array}{l}\text { (Irfan et al., } \\
\text { 2019) } \\
\text { (Rembet \& } \\
\text { Baramuli, } \\
\text { 2020) }\end{array}$ & $\begin{array}{l}\text { Positiv } \\
\text { e and } \\
\text { signific } \\
\text { ant } \\
\text { influen } \\
\text { ce }\end{array}$ & $\begin{array}{l}\text { Commer } \\
\text { cial Bank }\end{array}$ \\
\hline & & $\begin{array}{l}\text { (Dini \& } \\
\text { Manda, } \\
2020) \\
\text { (Hanafia \& } \\
\text { Karim, } \\
\text { 2020) }\end{array}$ & $\begin{array}{l}\text { The } \\
\text { positive } \\
\text { effect } \\
\text { is } \\
\text { insignif } \\
\text { icant }\end{array}$ & $\begin{array}{l}\text { SOEs } \\
\text { BUS dan } \\
\text { BPRS }\end{array}$ \\
\hline & & $\begin{array}{l}\text { (Abdurrohm } \\
\text { an, 2020) } \\
\text { (Sudirgo \& } \\
\text { Stevani, } \\
\text { 2019) }\end{array}$ & $\begin{array}{l}\text { Negativ } \\
\text { e and } \\
\text { signific } \\
\text { ant } \\
\text { influen } \\
\text { ce }\end{array}$ & $\begin{array}{l}\text { Commer } \\
\text { cial Bank } \\
\text { Commer } \\
\text { cial Bank }\end{array}$ \\
\hline & & $\begin{array}{l}\text { (Pinasti \& } \\
\text { Mustikawati } \\
\text { 2018) }\end{array}$ & $\begin{array}{l}\text { Negativ } \\
\text { e } \\
\text { influen } \\
\text { ce is } \\
\text { not } \\
\text { signific } \\
\text { ant }\end{array}$ & $\begin{array}{l}\text { Commer } \\
\text { cial Bank }\end{array}$ \\
\hline \multirow[t]{3}{*}{$\begin{array}{l}\text { Differenc } \\
\text { e in nim } \\
\text { research } \\
\text { results } \\
\text { on ROA }\end{array}$} & \multirow{3}{*}{$\begin{array}{l}\text { The } \\
\text { higher } \\
\text { the } \\
\text { NIM, } \\
\text { the } \\
\text { better } \\
\text { the } \\
\text { compa } \\
\text { ny's } \\
\text { financ } \\
\text { ial } \\
\text { perfor } \\
\text { mance } \\
\text {. NIM } \\
\text { has a } \\
\text { positiv } \\
\text { e } \\
\text { effect } \\
\text { on } \\
\text { ROA. }\end{array}$} & $\begin{array}{l}\text { (Good \& } \\
\text { Taswan, } \\
\text { 2019) } \\
\text { (Avrita \& } \\
\begin{array}{l}\text { Pangestuti, } \\
\text { 2016) }\end{array}\end{array}$ & $\begin{array}{l}\text { Positiv } \\
\text { e and } \\
\text { signific } \\
\text { ant } \\
\text { impact }\end{array}$ & $\begin{array}{l}\text { Commer } \\
\text { cial Bank } \\
\text { Commer } \\
\text { cial Bank }\end{array}$ \\
\hline & & $\begin{array}{l}\text { (Mismiwati, } \\
\text { 2016) }\end{array}$ & $\begin{array}{l}\text { Positiv } \\
\text { e and } \\
\text { insignif } \\
\text { icant } \\
\text { effect }\end{array}$ & $\begin{array}{l}\text { Rural } \\
\text { Bank }\end{array}$ \\
\hline & & $\begin{array}{l}\text { (Alaziz, } \\
2020)\end{array}$ & $\begin{array}{l}\text { Negativ } \\
\text { e and } \\
\text { signific } \\
\text { ant } \\
\text { influen } \\
\text { ce }\end{array}$ & $\begin{array}{l}\text { Commer } \\
\text { cial Bank }\end{array}$ \\
\hline $\begin{array}{l}\text { Differenc } \\
\text { e in NPL } \\
\text { research } \\
\text { results } \\
\text { on ROA }\end{array}$ & $\begin{array}{l}\text { The } \\
\text { higher } \\
\text { the } \\
\text { NPL, } \\
\text { the } \\
\text { lower }\end{array}$ & $\begin{array}{l}\text { (Nuryanto } \\
\text { et al., 2020) } \\
\text { (Dewi \& } \\
\text { Badjra, } \\
\text { 2020) }\end{array}$ & $\begin{array}{l}\text { Negativ } \\
\text { e and } \\
\text { signific } \\
\text { ant } \\
\text { influen } \\
\text { ce }\end{array}$ & $\begin{array}{l}\text { Commer } \\
\text { cial Bank } \\
\text { Commer } \\
\text { cial Bank }\end{array}$ \\
\hline
\end{tabular}




\begin{tabular}{|c|c|c|c|c|}
\hline & \multirow{3}{*}{$\begin{array}{l}\text { the } \\
\text { ROA. } \\
\text { NPL } \\
\text { negati } \\
\text { vely } \\
\text { affects } \\
\text { ROA. }\end{array}$} & & & \\
\hline & & $\begin{array}{l}\text { (Christaria } \\
\text { \& Grace, } \\
\text { 2016) }\end{array}$ & $\begin{array}{l}\text { Negativ } \\
\text { e and } \\
\text { insignif } \\
\text { icant } \\
\text { effect }\end{array}$ & $\begin{array}{l}\text { Commer } \\
\text { cial Bank }\end{array}$ \\
\hline & & $\begin{array}{l}\text { (Yusriani, } \\
\text { 2018) }\end{array}$ & $\begin{array}{l}\text { Positiv } \\
\text { e and } \\
\text { signific } \\
\text { ant } \\
\text { influen } \\
\text { ce }\end{array}$ & SOEs \\
\hline \multirow[t]{4}{*}{$\begin{array}{l}\text { Differenc } \\
\text { es in } \\
\text { BOPO } \\
\text { research } \\
\text { results } \\
\text { on ROA }\end{array}$} & \multirow{4}{*}{$\begin{array}{l}\text { The } \\
\text { higher } \\
\text { the } \\
\text { BOPO } \\
\text { will } \\
\text { decrea } \\
\text { se the } \\
\text { compa } \\
\text { ny's } \\
\text { ROA. } \\
\text { BOPO } \\
\text { negati } \\
\text { vely } \\
\text { affects } \\
\text { ROA }\end{array}$} & $\begin{array}{l}\text { (Dewi, } \\
\text { 2018) } \\
\text { (Hanafia \& } \\
\text { Karim, } \\
\text { 2020) }\end{array}$ & $\begin{array}{l}\text { Negativ } \\
\text { e and } \\
\text { signific } \\
\text { ant } \\
\text { influen } \\
\text { ce }\end{array}$ & $\begin{array}{l}\text { Commer } \\
\text { cial Bank } \\
\text { BUS dan } \\
\text { BPRS }\end{array}$ \\
\hline & & $\begin{array}{l}\text { (Nugroho et } \\
\text { al., 2019) }\end{array}$ & $\begin{array}{l}\text { Negativ } \\
\text { e } \\
\text { effects } \\
\text { are not } \\
\text { signific } \\
\text { ant }\end{array}$ & $\begin{array}{l}\text { National } \\
\text { Private } \\
\text { Commer } \\
\text { cial Bank }\end{array}$ \\
\hline & & $\begin{array}{l}\text { (Yusriani, } \\
\text { 2018) } \\
\text { (Nanda et } \\
\text { al., 2019) }\end{array}$ & $\begin{array}{l}\text { Positiv } \\
\text { e and } \\
\text { signific } \\
\text { ant } \\
\text { influen } \\
\text { ce }\end{array}$ & $\begin{array}{l}\text { SOEs } \\
\text { Islamic } \\
\text { Bank }\end{array}$ \\
\hline & & $\begin{array}{l}\text { (Zulvia, } \\
\text { 2020) }\end{array}$ & $\begin{array}{l}\text { Positiv } \\
\text { e and } \\
\text { insignif } \\
\text { icant } \\
\text { effect }\end{array}$ & $\begin{array}{l}\text { Sharia } \\
\text { General } \\
\text { Tub }\end{array}$ \\
\hline \multirow[t]{3}{*}{$\begin{array}{l}\text { Differenc } \\
\text { es in the } \\
\text { results of } \\
\text { LDR } \\
\text { research } \\
\text { on ROA }\end{array}$} & \multirow{2}{*}{$\begin{array}{l}\text { The } \\
\text { higher } \\
\text { the } \\
\text { LDR, } \\
\text { the } \\
\text { better } \\
\text { the } \\
\text { compa } \\
\text { ny's } \\
\text { financ } \\
\text { ial } \\
\text { perfor } \\
\text { mance } \\
\text {. LDR } \\
\text { positiv } \\
\text { ely } \\
\text { affects } \\
\text { ROA }\end{array}$} & $\begin{array}{l}\text { (Dewi et al., } \\
\text { 2015) } \\
\text { (Dewi, } \\
\text { 2018) }\end{array}$ & $\begin{array}{l}\text { Positiv } \\
\text { e and } \\
\text { positive } \\
\text { effects }\end{array}$ & $\begin{array}{l}\text { Commer } \\
\text { cial Bank } \\
\text { Commer } \\
\text { cial Bank }\end{array}$ \\
\hline & & $\begin{array}{l}\text { (Sudirgo \& } \\
\text { Stevani, } \\
\text { 2019) }\end{array}$ & $\begin{array}{l}\text { The } \\
\text { positive } \\
\text { effect } \\
\text { is } \\
\text { insignif } \\
\text { icant }\end{array}$ & $\begin{array}{l}\text { Commer } \\
\text { cial Bank }\end{array}$ \\
\hline & & $\begin{array}{l}\text { (Risalah et } \\
\text { al., 2018) }\end{array}$ & $\begin{array}{l}\text { Negativ } \\
\text { e and } \\
\text { signific }\end{array}$ & $\begin{array}{l}\text { Islamic } \\
\text { Bank }\end{array}$ \\
\hline
\end{tabular}

\begin{tabular}{|l|l|l|} 
& $\begin{array}{l}\text { ant } \\
\text { influen } \\
\text { ce }\end{array}$ & \\
\hline $\begin{array}{l}\text { (Rembet \& } \\
\text { Baramuli, }\end{array}$ & Negativ & National \\
2020) & effects & Self- \\
& Commer \\
& $\begin{array}{l}\text { are not } \\
\text { signific } \\
\text { cial Bank }\end{array}$ \\
& ant & \\
\hline
\end{tabular}

Based on the identification of previous research gaps and supported by the gap phenomenon that occurred in the research period, namely during 20102019, the researcher intends to conduct a study with the title "Capital Adequacy Influence, Market Risk, Credit Risk, Operational Risk and Liquidity on Bank Profitability (Case Study on Islamic Banks Registered with IDX and OJK Period 2010-2019)".

\section{Problems}

Based on the background of the problem and the gap of research, the formulation of the problem in this study is as follows:

1. Does CAR have a positive and significant effect on ROA on Islamic Banks?

2. Does NOM have a positive and significant effect on ROA on Islamic Banks?

3. Does NPF have a negative and significant effect on ROA on Islamic Banks?

4. Does BOPO have a negative and significant effect on ROA on Islamic banks?

5. Does FDR have a positive and significant effect on ROA in Islamic Banks?

\section{Research objectives}

Based on the formulation of the problem that has been explained, the purpose of this study is as follows:

1. To test and analyze whether CAR has a positive and significant ROA effect on Islamic Banks.

2. To test and analyze whether NOM has a positive and significant affection ROA on Islamic Banks.

3. To test and analyze whether NPF has a negative and significant effect on ROA on Islamic Banks.

4. To test and analyze whether BOPO has a negative and significant effect on ROA on Islamic Banks. 
5. To test and analyze whether FDR has a positive and significant affection ROA in Islamic Banks.

\section{LITERATURE REVIEW}

\section{Signalling Theory}

Signalling theory is one of the pillar theories in financial management. Signal theory indicates an information asymmetry between company management and parties who have an interest in the information.

Signal theory explains why companies present information for capital markets. Signaling theory is a management behavior in the company's prospects for the future. Signal theory predicts what information a company will provide, how information will be provided and when information will be provided. [53].

One of the efforts to reduce asymmetric information is to provide information by the company on investment decisions of parties outside the company [48]. If the announcement is positive, the market will react when the time of the announcement is received and when market participants receive the information, market participants will interpret and analyze the information as good news or bad news.

\section{Bank Sharia}

According to Law No. 21 of 2008 on Islamic Banking Chapter 1 Article 1 Islamic Banking is everything that concerns Islamic banks and Sharia business units, covering institutions, business activities, as well as ways and processes in carrying out their business activities. According to the Financial Services Authority (OJK), Islamic banks are banks that carry out their business activities based on Sharia principles and by their types consist of Sharia Commercial Bank (BUS) and Sharia People's Financing Bank (BPRS). The main purpose of the establishment of a sharia-based financial institution is as an effort by Muslims to base all aspects of their economic life based on the Quran and Sunnah.

Islamic banking in carrying out its business activities based on sharia principles of Sharia democracy, and the principle of prudence. The purpose of Islamic banking is to support the implementation of national development in order to improve justice, togetherness, and equitable welfare of the people (ojk.go.id).

In accordance with the codification of Islamic banking products issued by Bank Indonesia, Islamic banking products in Indonesia are as follows:

\section{Fund Raising Products}

a. Wadi'ah

Wadi'ah is a titipan. Wadi'ah can also be interpreted as pure titipan from one party to another, both as an individual and as a legal entity. Wadi'ah is divided into two, wadi'ah amanah and wadi'ah yad dhamanah. In wadi'ah the trust of funds deposited cannot be used or purely as titipan, while wasi'ah yad dhamanah funds from custody can be utilized. Wadi'ah yad dhamanah is what is used as an Islamic bank as a deposit or current account product.

\section{b. Mudharabah}

In the collection of funds, Islamic banks are served as mudharib (fund managers) and savers or customers as fund owners (shahibul maal). The owner of the internal funds will shahibul maal entrust the funds $100 \%$ to the mudharib as a party who has the skill to manage funds (mudharrib). The revenue share of the management of these funds is divided in accordance with the ratio that has been agreed by both parties. Mudharabah consists of two types, namely mudharabah mutlaqah, namely mudharabah mutlaqah, which is a cooperation agreement between sahibul mall and mudharib is not limited to the specifics of business, place, and time while still justified within the limits of syara' law. Mudharabah muqayyadah, which is a cooperation effort that will be limited in accordance with the will of the shahibul mall, while in the form of the smoothed.

\section{c. Funds Distribution Products}

The distribution of funds in Islamic banks in the form of financing will be mudharabah and musyarakah (with revenue sharing patterns), mudharabah and salam (with buying and selling patterns), and ijarah (with operational and financial rental patterns), as well as service-based complementary prosuk (phase-based service) such as qardh and other financial services.

\section{Banking Performance}

The performance of a company is very beneficial for many interested parties such as investors, creditors, analysts, financial consultants, the government, and the management of the company itself [42]. On the other hand, performance is something that must be achieved by every company, because performance is used as a reflection of the management ability to manage its resources [22]. The performance of the company can be known through a variety of variables and indicators. The variable used as a performance 
assessment is the financial statements of the company concerned.

In the financial statements there is information in the form of financial position and performance in the past that can be used as a reference in predicting future performance. Sourced from financial statements can be calculated a number of financial ratios used to measure financial performance. Financial performance is an important thing to be achieved by the company, because it gives an idea of the condition of a company, so that it can know the good bad of the situation [13]. One type of financial ratio analysis is by using CAMEL analysis.

\section{Research Design}

Based on the description that has been explained about the relationship between variables, it can be described to think about analyzing CAR, NOM, NPF, $\mathrm{BOPO}$ and FDR variables on financial performance in conventional banks and Islamic banks projected with ROA in figure 2 as follows:

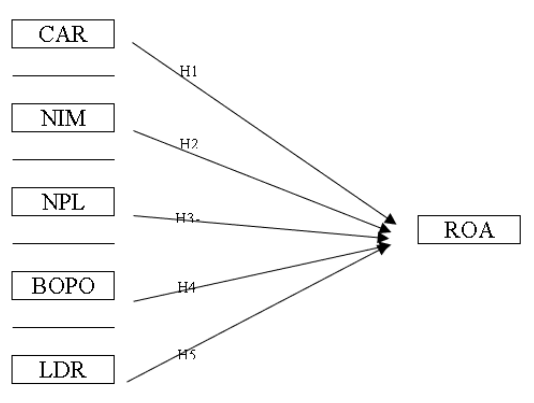

Figure 2. Research Framework

\section{Hypothesis}

Based on the foundation of previous theories and research and the frame of mind described above, the research that will be used to test independent variables that affect the dependent variable in this study as follows:

H1: CAR has a positive and significant effect on ROA in the sharia bank sub-sector

$\mathrm{H} 2$ : NOM has a positive and significant effect on ROA in the Islamic bank sub-sector.

H3: NPF has a negative and significant effect on ROA in the Islamic bank sub-sector.

H4: BOPO has a negative and significant effect on ROA in the Islamic bank sub-sector.

H5: FDR has a positive and significant effect on ROA in the Sharia bank sub-sector.

\section{METHODS}

\section{Data Sample}

The population of this study is all Sharia banks listed on the Indonesia Stock Exchange and the Financial Services Authority (OJK) which is 15 Islamic banks. Furthermore, the sample taken in this study is issuers in the banking sector registered with IDX and OJK in the period 2010-2019. Sample criteria for the following: 1) Banking companies registered with OJK in 2010-2019; 2) Islamic banking companies established before 2010. Thus the sample used in this study as many as 9 Islamic bank companies.

\section{Variables}

This study used ROA as a dependent variable. The reason ROA is used as a dependent variable in this study is because IT is used to measure the effectiveness of companies in making profits by utilizing assets owned [17]. High ROA shows that the bank use the assets it has well. ROA is formulated as follows:

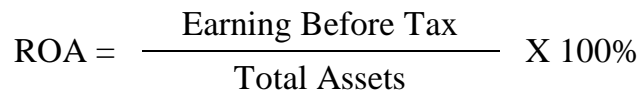

Independent variables are often referred to as free variables or variables $X$. The independent variables in this study are as follows:

\section{Capital Adequacy Ratio (CAR)}

CAR describes the company's ability to run business efficiently. This ability is related to the capital owned by the company. In addition, CAR demonstrates the ability to provide funds to bear the risk of any financing or risky productive assets [64]. This means that the higher the adequacy of capital to bear the risk [67]. The higher car will improve the performance of a bank [45]. The formula of CAR is:

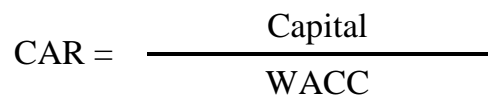

\section{Net Interest Margin (NIM)}

NIM is a financial ratio that measures a bank's ability to generate net interest income to manage large productive assets [21]. The higher nim owned by the bank leads to an increase in net interest income on productive assets managed by the bank concerned, causing the profitability of the company to increase [16]. According to the Circular Letter of Bank Indoenesia Number 3/30/DPNP, the NIM ratio is as follows:

$$
\mathrm{NIM}=\quad \text { Interest Earning }
$$




\section{Earning Assets}

\section{Non-Performing Loan (NPF)}

NPL is a ratio to measure the ability to ensure the risk of credit returns by debtors. NPL is used as one of the leading indicators in assessing a bank's performance. The higher this ratio, the worse the bank's credit quality and cause losses, conversely if the lower the NPL then the bank's profit or profitability will increase [8]. According to Bank Indonesia Circular Letter Number 3/30/DPNP, the NPL ratio is formulated as follows:

$$
\text { NPL }=\frac{\text { Bad Debt }}{\text { Total Credits }}
$$

4. Operating expenses to operating income (BOPO)

The BOPO ratio is used to measure the level of efficiency and ability of banks to control operating costs against their operating income [36]. The BOPO ratio is often referred to as the efficiency ratio. The greater the BOPO ratio owned by a bank shows the more inefficient the bank is in carrying out its operations. Banks that are increasingly ineffective in draining operating costs, the more likely the bank will be to suffer losses or bankruptcy.

$$
\mathrm{BOPO}=\frac{\text { Operation Expenses }}{\text { Operation Incomes }}
$$

\section{Loan to Deposit Ratio (LDR)}

The ratio of LDR as a liquidity proxy is a comparison between credit and The Third-Party Funds (DPK). This ratio is used to assess the liquidity of a bank to funds by dividing the amount of credit provided by the bank against third party funds. The higher the LDR ratio the higher the liquidity level [52]. The higher LDR will increase the bank's assumed profit that the bank can channel credit well, so that the increase in bank profits can improve the bank's performance as well [8]. According to Bank Indonesia Circular Letter Number 3/30/DPNP, the LDR ratio is formulated as follows:

$$
\text { LDR }=\frac{\text { Total Credits }}{\text { Third Fund }}
$$

\section{Data analysis technique}

Data analysis method is a method used in processing data so that the results of the data will be obtained to be interpreted. The analytical tool used in this study is Eviews 10. The data analysis methods in this study are descriptive analysis, model determination, classical assumption test, Gooodness of Fit testing, multiple regression analysis, and hypothesis testing.

\section{FINDINGS \& RESULT}

Descriptive statistics are used to describe ROA, CAR, NOM, NPF, BOPO, and FDR data as seen from average values, maximum values, minimum values, and standard deviation values. Table 3 Presents the results of descriptive statistics.

\begin{tabular}{|c|c|c|c|c|c|c|}
\hline & ROA & CAR & NOM & NPF & BOPO & FDR \\
\hline Mean & 0.907468 & 18.23481 & 4.353165 & 2.967468 & 90.88899 & 87.86899 \\
\hline Median & 0.950000 & 16.31000 & 4.640000 & 2.940000 & 91.01000 & 90.10000 \\
\hline \begin{tabular}{|l|} 
Maximum \\
\end{tabular} & 3.480000 & 38.30000 & 15.49000 & 7.850000 & 109.6200 & 105.6600 \\
\hline \begin{tabular}{|l|} 
Minimum \\
\end{tabular} & -1.120000 & 9.500000 & 0.050000 & 0.100000 & 47.60000 & 51.77000 \\
\hline Std. Dev. & 0.642708 & 6.423595 & 3.145098 & 1.726669 & 7.817480 & 9.469203 \\
\hline Skewness & 0.411539 & 1.157373 & 1.069397 & 0.419224 & -2.196822 & -1.138893 \\
\hline Kurtosis & 5.479051 & 3.935456 & 5.084427 & 3.217657 & 13.89270 & 5.383844 \\
\hline \begin{tabular}{|l} 
Jarque-Bera \\
\end{tabular} & 22.45955 & 20.51739 & 29.35929 & 2.469971 & $\begin{array}{l}454.1022 \\
\end{array}$ & \begin{tabular}{|l|}
35.78377 \\
\end{tabular} \\
\hline $\begin{array}{l}\text { Probability } \\
\end{array}$ & 0.000013 & 0.000035 & 0.000000 & 0.290839 & 0.000000 & 0.000000 \\
\hline Sum & 71.69000 & 1440.550 & 343.9000 & 234.4300 & 7180.230 & 6941.650 \\
\hline Sum Sq. Dev. & 32.21969 & 3218.481 & 771.5481 & 232.5481 & 4766.813 & 6993.933 \\
\hline $\begin{array}{l} \\
\text { Observations }\end{array}$ & 79 & 79 & 79 & 79 & 79 & 79 \\
\hline
\end{tabular}

Table 3 Results of Descriptive Statistical Tests of Sharia Bank Sub-Sectors

Compiled by: Author (2021)

The average ROA in the Islamic bank sub-sector is 0.907468 . This shows that the average company in the Islamic bank sub-sector has a profit of $0.9 \%$ from the management of assets owned. The standard deviation value is 0.6427 . This indicates that the distribution of data has a normal distribution because the average value is greater than the standard deviation value.

This type of research model uses regression panel data. Data panels are divided into three models, namely common effect model, fixed effect model, and random effect model. To determine the most appropriate model can be done with three tests, namely chow test, Hausman test, and multiplier Langrange test.

Here are the results of the chow test results in this study.

Table 4. Chow Test

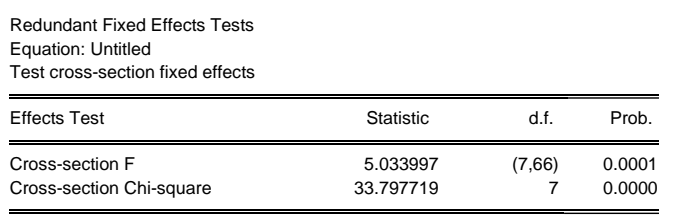

Based on the results of chow tests on Islamic bank sub-sectors shown in table 4 it can be known that the probability value of Cross-section Chi-square $<\alpha$, 
which is $0.000<0.05$. This indicates that the $\mathrm{H} 0$ was rejected and the $\mathrm{H} 1$ accepted which means the best model used is the fixed effect model.

The next test is the Hausman test. If the Hausman test selected is a random effect model, then it is necessary to do the next test, namely the multiplier langrage test (LM). The Hausman test is a test that is done after doing the chow test. The Hausman test is used to determine the best model used, whether fixed effect model or random effect model. The Hausman test uses chi-square distribution. Here are the results of the Hausman test in this study.

Table 5. Hausman Test

\begin{tabular}{cccc}
\multicolumn{6}{c}{$\begin{array}{c}\text { Correlated Random Effects - Hausman Test } \\
\text { Equation: Untitled } \\
\text { Test cross-section random effects }\end{array}$} & & \\
\hline \hline Test Summary & $\begin{array}{l}\text { Chi-Sq. } \\
\text { Statistic }\end{array}$ & Chi-Sq. d.f. & Prob. \\
\hline \hline Cross-section random & 2.249677 & 5 & 0.8136 \\
\hline \hline
\end{tabular}

Based on the results of the Hausman test on the Islamic bank sub-sector shown in table 5 it can be known that the probability value of Chi-square $>\alpha$, which is $0.8136>0.05$. This indicates that $\mathrm{HO}$ is accepted and $\mathrm{H} 1$ is rejected. This means that the model chosen is a random effect model. Thus, it is necessary to do the next test, namely the Lagrange multiplier test to choose the best model between common effect models. Or a random effect model.

Table 6. Langrage Multiplier Test

\begin{tabular}{lccc}
\hline \hline $\begin{array}{l}\text { Null (no rand. effect) } \\
\text { Alternative }\end{array}$ & $\begin{array}{c}\text { Cross-section } \\
\text { One-sided }\end{array}$ & $\begin{array}{c}\text { Period } \\
\text { One-sided }\end{array}$ & Both \\
\hline \hline Breusch-Pagan & 20.79451 & 3.032776 & $\begin{array}{l}23.82729 \\
(0.0000)\end{array}$ \\
& $(0.0816)$ & $(0.0000)$ \\
\hline
\end{tabular}

Based on the langrage multiplier test in the sharia bank sub-sector showed the result that the Breuschpagan value $<\alpha$ with a value of $0.000<0.05$. The value means that $\mathrm{H} 0$ is rejected and $\mathrm{H} 1$ is accepted, so the most appropriate panel data estimation model used in the study is the random effect model.

Multiple regression analysis is an analytical method used to test hypotheses. Multiple regression analysis in this research is used to test the influence of CAR, NIM, NPL, BOPO and LDR on ROA. Regression model equation as follows:

$\mathrm{ROA}=\alpha+\beta 1(\mathrm{CAR})+\beta 2(\mathrm{NOM})+\beta 3(\mathrm{NPF})+$ $\beta 4(\mathrm{BOPO})+\beta 5(\mathrm{FDR})+\boldsymbol{e}$
Table 7 Results of Sub-Sector Regression Test of Sharia Banks Registered in OJK

\begin{tabular}{|l|c|}
\hline \multirow{2}{*}{ Dependent variable: ROA } & \multicolumn{2}{|c|}{ Variabel } & Model \\
\hline \multirow{2}{*}{ CAR } & 0,4153 \\
\cline { 2 - 2 } & $-0,0049$ \\
\hline \multirow{2}{*}{ NIM } & $0,0364 *$ \\
\hline \multirow{2}{*}{ NPL } & 0,0244 \\
\hline \multirow{2}{*}{ BOPO } & 0,2321 \\
\cline { 2 - 2 } & $-0,0349$ \\
\hline \multirow{2}{*}{ LDR } & $0,0000 *$ \\
\cline { 2 - 2 } & $-0,0667$ \\
\hline \multirow{2}{*}{ Intercept } & 0,8036 \\
\cline { 2 - 2 } & $-0,0009$ \\
\hline Observation Unit & 0,0000 \\
\hline Adjusted R-Square & 5,6473 \\
\hline
\end{tabular}

Based on table 7 it can be known that the magnitude of the influence of independent variables on dependent variables by looking at intercept values, can be formulated the results as follows:

$\mathrm{ROA}=5,6473-0,0049 \mathrm{CAR}+0,0244 \mathrm{NIM}-$ 0,0349 NPL - 0,0667 BOPO - 0,0009 LDR + e

The $t$ test is essentially to determine the effect of independent variables on individual dependent variables. In this study the t test was used to determine the influence of CAR, NIM, NPL, BOPO and LDR variables on ROA variables indirectly. The $t$ test is done by looking at the probability of the variable being tested. If the probability value (prob value) $<0.05$, then $\mathrm{HO}$ is rejected which means that the independent variable affects the dependent variable individually. If the probability value (prob value) $>0.05$, then $\mathrm{H} 0$ is accepted which means that the independent variable has no impact on the dependent variable. The hypotheses in this study are as follows:

H0: individually has no effect on dependent variables

H1: individually affects dependent variables The following is the output of the test results $t$ on the sub-sector of Islamic bank banks. 
Table 8 Result of Sub-Sector T-Test of Sharia Bank Register in OJK

\begin{tabular}{crrrr}
\hline \hline Variable & Coefficient & Std. Error & t-Statistic & Prob. \\
\hline \hline C & 5.647323 & 0.500205 & 11.29003 & 0.0000 \\
NCAR & -0.004927 & 0.006010 & -0.819791 & 0.4153 \\
NNOM & 0.025444 & 0.011912 & 2.136119 & 0.0364 \\
NNPF & -0.034890 & 0.028922 & -1.206338 & 0.2321 \\
NBOPO & -0.066663 & 0.005143 & -12.96204 & 0.0000 \\
NFDR & -0.000919 & 0.003682 & -0.249760 & 0.8036 \\
\hline \hline
\end{tabular}

Based on research and discussion in chapter four, it can be concluded that:

1. CAR has no effect on ROA in the sharia bank subsector.

2. NOM has a positive effect on ROA in the sharia bank sub-sector.

3. NPF has no effect on ROA in the sharia bank subsector.

4. BOPO negatively affects ROA in the sharia bank sub-sector.

5. FDR has no effect on ROA in the sharia bank subsector.

\section{REFERENCES}

[1] Abdurrohman. . Pengaruh Capital Adequacy Ratio (CAR), Loan to Deposit Ratio (LDR), dan Non Performing Loan (NPL) Terhadap Return on Assets (ROA) Pada Sektor Perbankan di Bursa Efek Indonesia. Jurnal Bisnis \& Manajemenurnal Bisnis \& Manajemen, 2(2), 2020, pp 102-111.

[2] Akbar, D. A., Analisis Pengaruh Ukuran Perusahaan, Kecukupan Modal, Kualitas Aktiva Produktif (KAP) Dan Likuiditas Terhadap Kinerja Keuangan (Studi Kasus Bank Umum Syariah di Indonesia Periode 2007-2011). Jurnal Ilmiah STIE MDP, 3(1), 2013, pp 66-82.

[3] Alaziz, M., Effect Of Car, Ldr, Roa, Roa And Nim Toward The Commercial Bank In Indonesia. International Journal of Economics, Business and Accounting Research, 53(9), 2020, pp 225-234.

[4] Almunawwoh, M., \& Marlina, R.,

[5] Pengaruh CAR, NPF dan FDR Terhadap Profitabilitas Bank Syariah Di Indonesia. Journal of Chemical Information and Modeling, 53(9), 2018, pp 1689-1699.

[6] Amalia, S., Agustriyana, D., \& Susanti, N. Does the Capital Adequacy Ratio (CAR), Non Performing Loans ( NPL ), and Net Interest Margin ( NIM ) Affect the Profitability of
Banks ? : Case of Indonesia. IColSSE, 2020, pp 517-524.

[7] Anggraeni. Analisa Kinerja Keuangan Perusahaan Pertambangan Yang Terdaftar Dalam Bursa Efek Indonesia. ECo-Buss, 1(3), 2019, pp 203-209.

[8] Armansyah, A., \& Ritha, H. Analisis Pengaruh Capital Adequacy Ratio (Car), Loan To Deposit Ratio (Ldr) Biaya Operasional Pendapatan Operasional (Bopo) Dan Non Performing Loan (Npl) Terhadap Roa Pt Bank Central Asia Tbk. Periode Tahun 2010-2016. Perbanas Review, 3(2), 2018, pp 139-146.

[9] Avrita, R. D., \& Pangestuti, I. R. D. Analisis Pengaruh CAR, NPL, LDR, NIM, dan BOPO Terhadap Profitabilitas Bank (Perbandingan Bank Umum Go Public Dan Bank Umum Non Go Public Di Indonesia Periode Tahun 20112014). Diponegoro Journal of Management, 5(2), 2016, pp 1-13. https://ejournal3.undip.ac.id/index.php/djom/arti cle/download/13964/13500

[10] Bagus, S., \& Taswan. Pengaruh npl, ldr, nim, dan car terhadap roa pada bank umum yang go publik di bei. MADIC, September, 2019, pp 43-49.

[11] Christaria, F., \& Kurnia, R., Accounting and Finance Review The Impact of Financial Ratios, Operational Efficiency and Non-Performing Loan Towards Commercial Bank Profitability. Acc. Fin. Review, 1(1), 2016a, pp 43-50. www.gatrenterprise.com/GATRJournals/index.h $\underline{\mathrm{tml}}$

[12] Christaria, F., \& Kurnia, R. Accounting and Finance Review The Impact of Financial Ratios, Operational Efficiency and Non-Performing Loan Towards Commercial Bank Profitability. Acc. Fin. Review, 1(1), 2016b, pp 43-50.

[13] Christaria, F., \& Kurnia, R., The Impact of Financial Ratios, Operational Efficiency and Non Performing Loan Towards Commercial Bank Profitability. Global Academy of Training \& Research Journal, 1(1), 2016c, pp 43-50.

[14] Dewi, A. S., Pengaruh CAR, BOPO, NPL, NIM, dan LDR terhadap ROA pada Perusahaan di Sektor Perbankan yang Terdaftar di BEI Periode 2012-2016. Jurnal Pundi, 1(3), 2018, pp 223 236. https://doi.org/10.31575/jp.v1i3.55

[15] Dewi, N. K. C., \& Badjra, I. B., the Effect of Npl, Ldr and Operational Cost of Operational Income 
on Roa. American Journal of Humanities and Social Sciences Research, 7, 2020, pp 171-178. www.ajhssr.com

[16] Dewi, N. K. V. C., Cipta, W. dan, \& Kirya, I. K., Pengaruh LDR, LAR, DER dan CR Terhadap ROA. Journal Bisma Universitas Pendidikan Ganesha, 3(1), 2015, pp 1-10. https://ejournal.undiksha.ac.id/index.php/JJM/ar ticle/view/4655/3552

[17] Dini, N., \& Manda, G. S., Pengaruh Car, Npl, Nim, Bopo, Ldr Dan Suku Bunga Sbi Terhadap Roa Bank Bumn Periode Tahun 2009-2018. EJurnal Ekonomi Dan Bisnis Universitas Udayana, 9, 2020, pp 899. https://doi.org/10.24843/eeb.2020.v09.i09.p05

[18] Endraswati, H., Gender Diversity in Board of Directors and Firm Performance: A Study in Indonesia Sharia Banks. Review of Integrative Business and Economics Research, 7(1), 2018, pp 299. www.sindonews.com,

[19] Fadrul, \& Asyari, H., Faktor - faktor yang mempengaruhi profitabilitas bank syariah di indonesia tahun 2011-2015. Cano Economos, 7(1), 2018, pp 25-38.

[20] Gumanti, T. A., Teori Sinyal Dalam Manajemen Keuangan. Manajemen Dan Usahawan Indonesia, September, 2009, pp 1-29.

[21] Hanafia, F., \& Karim, A., Analisis CAR, BOPO, NPF, FDR, NOM, Dan DPK Terhadap Profitabilitas (ROA) Pada Bank Syari'ah Di Indonesia. Target: Jurnal Manajemen Bisnis, 2(1), 2020, pp 36-46. https://doi.org/10.30812/target.v2i1.697

[22] Hasibuan, T. F. H., Erlina, \& Zainal, A., The Inflence Of Capital Adequacy Ratio, Loan to Depost Ratio, Non Performing Loan, Net Interest Margin, And Operational Efficiency Ratio On Share Prices Wuth Retuen On Assets As An Intervening Variabels In Banking Company Listed On IDX. 44(12), 2019, pp 2-8.

[23] Hutagalung, E. N., Djumahir, \& Ratnawari, K., Analisa Rasio Keuangan terhadap Kinerja Bank Umum di Indonesia. Jurnal Aplikasi Manajemen, 11(1), 2013, pp 122-130.

[24] Ichsan, R. N., \& Nasution, L., Analisis Pengaruh NPL, CAR, BOPO dan IRR Terhadap Pertumbuhan Kinerja Keuangan Bank yang Terdaftar di Bursa Efek Indoensia Periode 2011-
2015. Jurnal Keuangan \& Perbankan, 8(1), 2020, pp 51-59.

[25] Indyarwati, E. V., \& Handayani, N., PENGARUH RASIO CAMEL TERHADAP KINERJA KEUANGAN PERBANKAN SYARIAH. Jurnal Ilmu Dan Riset Akuntansi, 6(8), 2017, pp 1-15.

[26] Irfan, M., Suwendra, I. W., \& Sujana, I. N., Pengaruh Capital Adequacy Ratio (Car), Loan To Deposit Ratio (Ldr), Dan Net Interest Margin (Nim) Terhadap Return on Assets (Roa) Pada Bank Umum Swasta Nasional Devisa Yang Terdaftar Di Bursa Efek Indonesia Tahun 20152017. Jurnal Pendidikan Ekonomi Undiksha, 11(1), 2019, pp 296. https://doi.org/10.23887/jipe.v11i1.20162

[27] Khalifaturofi'ah, S. O., \& Nasution, Z., Analisis Faktor-Faktor Yang Mempengaruhi Kinerja Keuangan Perbankan Di Indoensia. Jurnal Perbankan Syariah, 1(2), 2016, pp 42-64.

[28] Kinanti, A. R., \& Purwohandoko, P., Influence of Third-Party Funds, Car, Npf and Fdr Towards the Return on Assets of Islamic Banks in Indonesia. JEMA: Jurnal Ilmiah Bidang Akuntansi Dan Manajemen, 14(02), 2017, pp 135. https://doi.org/10.31106/jema.v14i02.524

[29] Komara, E., Influence of Bank Health Ratio on Financial Performance of Islamic Commercial Bank. Jurnal Ilmu Manajemen \& Ekonomika, 10(1), 2018, pp 1. https://doi.org/10.35384/jime.v10i1.57

[30] Koto, M., \& Lubis, I. R., Bank Umum Swasta Nasional dalam Analisa Return On Asset, Loan To Deposit Ratio dan BOPO. 1(2), 2020, pp 6875

[31] Liora, E. F., Taufik, T., \& Anisma, Y. (n.d.). Analisis Perbandingan Kinerja Keuangan Bank Konvensional Dan Bank Syariah Yang Terdaftar Di Bank Indoensia. Jom Fekom, 1(2), pp 1-15.

[32] Lukitasari, Y. P., \& Kartika, A., Analisis Pengaruh Dana Pihak Ketiga, Bopo, Car, Ldr Dan Npl Terhadap Kinerja Keuangan Pada Sektor Perbankan Yang Terdaftar Di Bursa Efek Indonesia. Students' Journal of Accounting and Banking, 4(1), 2015, pp 28-39.

[33] Maria, A., Pengaruh Car, Bopo, Nim, Npl Dan Ldr Terhadap Roa: Studi Kasus Pada 10 Bank Terbaik Di Indonesia. Jurnal Ilmiah Mahasiswa Universitas Surabaya, 4(1), 2015, pp 1-19. 
[34] Martiningtiyas, C. R., \& Nitinegeri, D. T., The Effect of Non-Performing Loans on Profitability in Banking Sector in Indonesia. 151(Icmae), 2020 , $\mathrm{pp}$ 64-67. https://doi.org/10.2991/aebmr.k.200915.016

[35] Mawaddah, N., Faktor-Faktor Yang Mempengaruhi Profitabilitas Bank Syariah. Etikonomi, 14(2). 2015, https://doi.org/10.15408/etk.v14i2.2273

[36] Mesrawati, purba suryana vieri dan purba safitri ade., Pengaruh BOPO, LDR, NPL Terhadap ROA Perusahaan Perbankan Yang Terdaftar di BEI. Jurnal Akuntansi Dan Ekonomika, 9(1), 2019, pp 6.

[37] Mismiwati, Pengaruh Car, Nim, Bopo, Ldr Dan Npl Terhadap Roa (Studi Pada Pt. Bpd Sumsel Babel). I-Finance, 2(1), 2016, pp 55-74.

[38] Nanda, A. S., Hasan, A. F., \& Aristyanto, E., Pengaruh CAR dan BOPO Terhadap ROA pada Bank Syariah pada Tahun 2011-2018 (The Effect of CAR and BOPO Against ROA in Islamic Banking in 2011-2018). Perisai: Islamic Banking and Finance Journal, 3(1), 2019, pp 19. https://doi.org/10.21070/perisai.v3i1.2160

[39] Nugroho, Daniel, Mangantar, M., \& Tulung, J. E., Pengaruh Car, Bopo, Nim, Dan Npl Terhadap Roa Industri Bank Umum Swasta Nasional Buku 3 Periode 2014 -2018. Jurnal EMBA: Jurnal Riset Ekonomi, Manajemen, Bisnis Dan Akuntansi, 2019, https://doi.org/10.35794/emba.v7i3.25038

[40] Nuryanto, U. W., Salam, A. F., Sari, R. P., \& Suleman, D., Pengaruh Rasio Kecukupan Modal, Likuiditas, Risiko Kredit dan Efisiensi Biaya Terhadap Profitabilitas Pada Bank Go Public. Moneter - Jurnal Akuntansi Dan Keuangan, 7(1), 2020, pp 1-9. https://doi.org/10.31294/moneter.v7i1.6777

[41] Pandoyo, \& Samsuddin., Influence of Car, Ldr, $\mathrm{Npl}$ and Bopo on Roa on Commercial Banks Listed on the Indonesia Stock Exchange in 20102016. Journal of Economics, Finance and Management Studies, 03(12), 2020, pp 296-302. https://doi.org/10.47191/jefms/v3-i12-11

[42] Pandoyo, \& Samsudin., Influence of Car, Ldr, Npl and Bopo on Roa on Commercial Banks Listed on the Indonesia Stock Exchange in 20102016. Journal of Economics, Finance and
Management Studies, 03(12), 2020, pp 296-302. https://doi.org/10.47191/jefms/v3-i12-11

[43] Paramitha, D. A., \& Astuti, P., Analisis Perbandingan Kinerja Keuangan Pada Bank Syariah dan. Jurnal Akuntansi \& Ekonomi FE UN PGRI Kediri, 3(2), 2018, pp 38-50.

[44] Pinasti, W. F., \& Mustikawati, R. I., Pengaruh Car, Bopo, Npl, Nim Dan Ldr Terhadap Profitabilitas Bank Umum Periode 2011-2015. Nominal, Barometer Riset Akuntansi Dan Manajemen, 2018, https://doi.org/10.21831/nominal.v7i1.19365

[45] Pramudyani, D. A., \& Hartono, U., Profitabilitas Pada Bank Busn Non Devisa Yang Terdaftar Di Indonesia Periode 2012 - 2016. UNEJ EProceeding, 2018, pp 535-547.

[46] Purnamasari, G. A. Y., \& Ariyanto, D., ANALISIS PERBANDINGAN KINERJA KEUANGAN BANK KONVENSIONAL DAN BANK SYARIAH (Periode 2012-2014). Jurnal Online Mahasiswa Fakultas Ekonomi Universitas Riau, 15(1), 2016, pp 82-110.

[47] Rembet, W. E. C., \& Baramuli, D. N., Pengaruh Car, Npl, Nim, Bopo, Ldr Terhadap Return on Asset (Roa) (Studi Pada Bank Umum Swasta Nasional Devisa Yang Terdaftar Di Bei). Jurnal EMBA: Jurnal Riset Ekonomi, Manajemen, Bisnis Dan Akuntansi, 8(3), 2020, pp 342-352. https://doi.org/10.35794/emba.v8i3.30085

[48] Risalah, S., Anshori, M. Y., \& Primasari, N. S., The Impact of CAR, BOPO, NPF, FDR, DPK and Profit Sharing on ROA of Sharia Banks Listed in Bank Indonesia (Study at Sharia Commercial Banks). International Conference on Technopreneurship and Education, 2018, pp 240-245.

[49] Rokhlinasari, S., Teori-Teori dalam Pengungkapan Informasi Corporate Social Responbility Perbankan. Al-Amwal:Jurnal Ekonomi Dan Perbankan Syari'ah, 7(1), 2016, pp 1-11.

[50] Saerang, I., Tommy, P., \& Christiano, M., Analisis Terhadap Rasio-rasio Keuangan Untuk Mengukur Profitabilitas Pada Bank-bank Swasta Yang Go Public Di Bursa Efek Indonesia. Jurnal Riset Ekonomi, Manajemen, Bisnis Dan Akuntansi, 2(4), 2014, pp 817-830. https://doi.org/10.35794/emba.v2i4.6490 
[51] Setiani, N., Gagah, E., \& Fathoni, A., Analysis Of Effect Of CAR, NPF, FDR, And BOPO ON ROA (Study at Shariah Commercial Bank in Indonesia Period 2012-2016). Manajemen. 2018.

[52] Setiawati, E., Rois, D. I. N., \& Aini, I. N., PENGARUH KECUKUPAN MODAL , RISIKO PEMBIAYAAN , EFISIENI ( Studi Pada Bank Syariah dan Bank Konvensional di Indonesia ) Pendahuluan Kajian Pustaka dan Pengembangan Hipotesis. Riset Akuntansi Dan Keuangan Indonesia, 2(2), 2017, pp 109-120.

[53] Sinung, D., Wardiningsih, S. S., \& Wibowo, E., Analisis Pengaruh NIM, BOPO, LDR dan NPL Terhadap Profitabilitas Pada Bank Pemerintah dan Bank Umum Swasta Nasional Di Bursa Efek Indonesia. Jurnal Ekonomi Dan Kewirausahaan, 16(1), 2016, pp 30-40.

[54] Sudirgo, T., \& Stevani. Analisis CAR, BOPO, NPL, dan LDR Terhadap ROA Perusahaan Perbankan. Jurnal Multiparadigma Akuntansi, I(3), 2019, pp 863-871.

[55] Sukmadewi, R., The Effect of Capital Adequacy Ratio, Loan to Deposit Ratio, Operating-Income Ratio, Non-Performing Loans, Net Interest Margin on Banking Financial Performance. 2(2), 2020, pp 1-10.

[56] Sunaryo, D., The Effect Of Capital Adequacy Ratio (CAR), Net Interest Margin (NIM), NonPerforming Loan (NPL), and Loan To Deposit Ratio (LDR) Against Return On Asset (ROA) In General Banks In Southeast Asia. Ilomata International Journal of Management, 1 No. 4(4), 2020, pp 149-158.

[57] Susanto, Heri \& Kholis, N., Analisis Rasio Keuangan Terhadap Profitabilitas Pada Perbankan Indonesia. E-Jurnal LP3M STIEBBANK, 7(1), 2016, pp 11-12.

[58] Syamsiah, Mus, A. R., \& Djamereng, A., Pengaruh Capital Adequacy Ratio (CAR), Loan to Deposit Ratio (LDR), Biaya Operasional dan Pendaptan Operasional (BOPO) terhadap Return on Asset (ROA) pada Perbankan yang Terdaftar di Bursa Efek Indonesia. Jurnal Magister Manajemen Universitas Muslim Indoensia, 8, 2021, pp 1.

[59] Vivin, Y. A., \& Wahono, B., Analisis Perbandingan Kinerja Keuangan Bank Umum Syariah dengan Bank Umum Konvensional di
Indonesia. E-Jurnal Riset Manajemen, 2017, pp 77-97.

[60] Warsa, M., \& Mustanda, I., Pengaruh Car, Ldr Dan Npl Terhadap Roa Pada Sektor Perbankan Di Bursa Efek Indonesia. E-Jurnal Manajemen Universitas Udayana, 5(5), 2016, pp 253810.

[61] Wibisono, M. Y., \& Wahyuni, S., Pengaruh CAR,N PF, BOPO, FDR, Terhadap Roa yang Dimediasi Oleh NOM. Jurnal Bisnis \& Manajemen, 17(1), 2017, pp 41-62.

[62] Wibowo, E. S., \& Syaichu, M., Analisis Pengaruh Suku Bunga, Inflasi, CAR, BOPO, NPF terhadap Profitabilitas Bank Syariah. Dopenogoro Journal Od Management, 2(2), 2013, pp 1-10.

[63] Wijaya, J. H., \& Yudawisastra, H. G., Influence of capital adequacy ratio, net interest margin and liquidity ratio against profitability ratio. International Journal of Innovation, Creativity and Change, 6(6), 2019, pp 268-277.

[64] Yudha, A., Chabachib, M., Rini, I., \& Pangestuti, D., Analysis Of The Effect Of Npl, Nim, Non Interest Income, And Ldr Toward Roa With Size As Control VariableS (Differences Study on Domestic and Foreign Banks Listed on BEI Period 2010-2015), 26(2), 2018, pp 100-113. https://doi.org/10.14710/jbs.26.2.100-113

[65] Yundi, N. F., \& Sudarsono, H., Pengaruh Kinerja Keuangan terhadap Return on Asset (ROA) Bank Syariah di Indonesia. Al-Amwal: Jurnal Ekonomi Dan Perbankan Syari'ah, 10(1), 2018, $\mathrm{pp}$

18. https://doi.org/10.24235/amwal.v10i1.2759

[66] Yusriani. Pengaruh CAR, NPL, BOPO dan LDR Terhadap Profitabilitas Pada Bank Umum Milik Negara Persero di Bursa Efek Indonesia. Jurnal Riset Edisi XXV, 4(002), 2018, pp 1-17.

[67] Zulfiah, F., \& Susilowibowo, J., Pengaruh inflasi, BI rate, Capital Adequacy Ratio (CAR), Non Performing Finance (NPF), Biaya Operasional dan Pendapatan Operasional (BOPO) terhadap profitabilitas Bank Umum Syariah periode 2008-2012. Jurnal Ilmu Manajemen, 2(3), 2014, pp 759-770.

[68] Zulvia, Y., Faktor-Faktor Yang Mempengaruhi Kinerja Keuangan Bank Umum Syariah Di Indonesia. Jurnal Benefita, 5(1), 2020, pp 50-61. 